\title{
Plant quality index of caracolillo (Ormosia macrocalyx Ducke), in nursery stage with controlled release fertilizers
}

\author{
Hernández- Sánchez Gerardo ${ }^{1}$, Obrador-Olán José J. ${ }^{1 *}$, Juárez-López José $\mathrm{F}^{1}{ }^{1}$, \\ Arreola-Enríquez Jesús ${ }^{2}$, García-López Eustolia ${ }^{1}$, Gastillo-Arias Edith de los Á. ${ }^{1}$ \\ ${ }^{1}$ Colegio de Postgraduados, Campus Tabasco. Periférico Carlos A. Molina S/N, H. Cárdenas, Tabasco, \\ México. C.P. 86500. \\ 2 Colegio de Postgraduados, Campus Campeche. Carretera Haltunchén-Edzná, Champotón, Campeche, \\ México. C.P. 24450. \\ * Correspondence: obradoro@colpos.mx
}

\begin{abstract}
Objective: To evaluate, in a nursery, the effect of two controlled release fertilizers in three concentrations on the growth components and quality index in caracolillo seedlings.

Design/Methodology/Approach: A factorial arrangement $(2 \times 3)$ housed in a completely randomized design was used, with seven treatments and twelve repetitions. For three months, the growth of caracolillo plants maintained in $310 \mathrm{~cm}^{3}$ polyethylene tubes, with a substrate of peat moss, vermiculite, agrolite and soil (2:1:1:1), plus controlled release fertilizer (CRF) Basacote ${ }^{\circledR} 9 \mathrm{M}$ (16-8-12) and Multicote ${ }^{\circledR} 12 \mathrm{M}$ (18-6-12), in three doses each: 10 (low), 20 (medium) and $30 \mathrm{~kg} \mathrm{~m}^{-3}$ (high), in addition to a control without conventional fertilization (CF) $17 \mathrm{~N}-17 \mathrm{P}-17 \mathrm{~K}$ in doses of $10 \mathrm{~kg} \mathrm{~m}^{-3}$. The variables height, diameter, leaf number, robustness index $(\mathrm{RI})$, aerial/root dry biomass ratio (ADB/RDB R) and Dickson's quality index (DQI) were measured. The means were compared by Tukey's test at a 5\% confidence level.

Results: Basacote ${ }^{\circledR}$ and Multicote ${ }^{\circledR}$ fertilizers in low doses allowed an adequate growth and development in caracolillo plants, which was reflected in the variables height, diameter and number of leaves. The RI and DQI indices presented values within the normal ranges, while those of ADB/RDB R were rather low, but in the three cases there were no statistical differences.

Study Limitations/Implications: Based on the results obtained, it is recommended to continue monitoring the studied plants in the field, which would allow adjustments in the initial fertilization doses.

Findings/Conclusions: The low doses $\left(10 \mathrm{~kg} \mathrm{~m}^{-3}\right)$ of the controlled release fertilizers Basacote ${ }^{\circledR}$ and Multicote ${ }^{\circledR}$ showed the best results in the growth and development of caracolillo in the nursery stage, but the $\mathrm{RI}, \mathrm{ADB} / \mathrm{RDB} \mathrm{R}$ and DQI indices did not present statistical differences.
\end{abstract}

Gitation: Hernández- Sánchez G., Obrador-Olán J. J., Juárez-López J. F., Arreola-Enríquez J., García-López E., \& Castillo-Arias E. de los Á.(2021) Plant quality index of caracolillo (Ormosia macrocalyx Ducke), in nursery stage with controlled release fertilizers. Agro Productividad. https://doi. org/10.32854/agrop.v14i10.1862

Editor in Chief: Dr. Jorge Cadena Iñiguez

Received: March 23, 2021. Accepted: September 12, 2021. Published on-line: November 8, 2021 Commercial 4.0 International license.
Keywords: Robustness, Basacote, Multicote, doses.

\section{INTRODUCTION}

Southeastern Mexico is one of the regions with the greatest forestry vocation, reason why there is a significant increase in areas with forest plantations, which implies an increase in the production of nursery plants (Escamilla-Hernández et al., 2015). In this sphere, one of the main problems to be solved is the production of vigorous and high quality plants, especially for native forest species (Carpenedo et al., 2016). The species Ormosia macrocalyx Ducke, commonly known as caracolillo, is listed in NOM-059 (SEMARNAT, 2010) as an endangered species 
(P). From an ecological perspective, it is important because it reaches nodulation rates by nitrifying bacteria of $48.9 \mathrm{mg} \mathrm{g}^{-1}$, and as a seedling it responds favorably to high concentrations of $\mathrm{CO}_{2}$ (700 ppm approximately) (Vargas-Simón et al., 2018). It produces bright red seeds that are used to make necklaces, bracelets, earrings, curtains and ornaments, and its wood is considered valuable (SERFOR, 2016), important in cabinetmaking and carpentry, in the construction of bridges, canoes, railroad sleepers and house constructions (Vargas-Simón et al., 2018). In livestock farming, it is used as shade for the livestock and, to a lesser extent, for round wood posts (Pérez-Hernández et al., 2011).

The success of forest plantations depends on the quality of the plants produced in the nursery (Landis et al., 2004), which Prieto and Sáenz (2011) define as the capacity of the plants to adapt and develop to the climate and soil conditions of the plantation site, and depends largely on their morphological and physiological genetic characteristics. Morphological attributes such as height, root collar diameter, root and stem dry weight, together with the relationships that can be established with these attributes, called morphological indices, among which robustness, proportion of aerial and root parts, and Dickson's index stand out, allow characterizing the quality of the plant produced in nursery in a quantitative way; this, in turn, allows making better decisions on the desired characteristics for the production of quality plants (Prieto et al., 2009; Sáenz et al., 2010).

At the national scale the survival rate of plantations is $50 \%$ one year after their establishment in the field, and the main causes of death are associated with the low quality of plants produced in nursery (Orozco-Gutiérrez et al., 2010). After irrigation, fertilization is the cultural practice that most directly influences this key attribute of container-grown plants (Oliet et al., 1999). According to Castro-Garibay et al. (2018), in most nurseries plant nutrition is generally done with water soluble fertilizers (WSF) applied with irrigation. This form of fertilization has disadvantages, such as nutrient loss by leaching, which can sometimes cause over-fertilization and promote an imbalance between the roots and the rest of the plant. Therefore, to solve this problem, controlled release fertilizers (CRF) are applied, which gradually transfer nutrients to the substrate, minimizing the risk of toxicity and reducing losses from leaching. In Mexico, the use of CRF in the production of forest plants is still incipient, although they are gradually entering the market. It must be considered that not all plants have the same nutritional needs, which is why applying and checking doses of these fertilizers through trials allows establishing their best use and at the same time determining nutritional requirements for each species (Terán-Soto, 2018). Based on the above, the effect of two controlled release fertilizers on Ormosia macrocalyx Ducke plants during their growth in the nursery stage was determined. Specifically, the effect of three concentration levels of two CRFs on morphological attributes and plant quality indices was evaluated.

\section{MATERIALS AND METHODS}

The study was carried out in the area of the facilities of Colegio de Postgraduados Campus Tabasco (Figure 3), located at Periférico Carlos A. Molina s/n, km. 3.5 Huimanguillo, Tabasco, Mexico. According to the Köpeen classification system, the climate is classified as tropical Am (g) "w" (warm-humid) with abundant summer rains, with average annual 
temperatures of $26.7^{\circ} \mathrm{C}$, and precipitation of 2,240 $\mathrm{mm}$ with a dry season in the months of March and April where less than $50 \mathrm{~mm}$ falls per month, and other rainy months such as September and October where precipitation is close to $400 \mathrm{~mm}$ per month (Palma-López et al., 2007).

The seed came from a collection made in the area of the Experimental Field of the Tabasco-CP Campus, located at km 21 of the Cárdenas-Coatzacoalcos Federal Highway. Seed germination was conducted in greenhouse in cotyledon stage (seedlings), where it was scarified to accelerate its germination, and 15 days after emerged the seedling was transplanted to $310 \mathrm{~cm}^{3}$ polyethylene tubes, placed in polypropylene trays for 54 tubes, using 12 of them to place the experimental units corresponding to each treatment, leaving a central row of six cells for the separation between plants (Carpenedo et al., 2016), placing them on a wooden structure inside the greenhouse (Castro-Garibay $e t$ al., 2018).

A factorial arrangement $(2 \times 3)$ was used in a completely randomized design, with seven treatments, of which six resulted from the factorial combination of two controlled release fertilizers: Basacote ${ }^{\circledR} 9 \mathrm{M}$ (16-8-12) and Multicote ${ }^{\circledR} 12 \mathrm{M}$ (18-6-12), considering three doses: low, medium and high $\left(10,20\right.$ and $30 \mathrm{~kg} \mathrm{~m}^{-3}$ respectively) for each one, plus a control without fertilization. There were 12 replicates per treatment, each plant being an experimental unit, for a total of 84 experimental units.

Seedlings were evaluated for three months. Height was measured in centimeters (ruler $\pm 0.01 \mathrm{~cm}$ ), from the base of the stem to the growing apex. For diameter, a QL-V series digital Vernier caliper of $0-150 \mathrm{~mm} / 0-6$, resolution $0.01 \mathrm{~mm}$, accuracy $\pm 0.02 \mathrm{~mm}$, was used; the root collar was measured in millimeters (Villalón-Mendoza et al., 2016). The number of leaves was obtained by counting each of the leaves of the plants in the treatments. The aerial and root biomass was quantified at the end of the experiment (MaldonadoBenítez et al., 2011 ).

The aerial part (leaves and stems) was separated from the radical part (roots) in paper bags that were placed in a SHEL model CE5F oven with forced circulation for 72 hours at a constant temperature of $60^{\circ} \mathrm{C}$. At the end, each part was weighed on a VELAB model VE5000 analytical balance with accuracy of $0.0001 \mathrm{~g}$ (González-Orozco et al., 2018). With the data of these variables, the calculation of plant quality indexes was performed: robustness index $(\mathrm{RI})$, aerial and root dry biomass ratio (ADB/RDB R) and Dickson's quality index (DQI) (Reyes-Castro et al., 2020), whose values were classified as: high, medium and low (Table 1).

The calculation of the indices and their classification was based on Escamilla-Hernández et al. (2015).

$$
\begin{gathered}
A D B / R D B R=\frac{\text { Aerial Dry Biomass }(g)}{\text { Root Dry Biomass }(g)} \\
R I=\frac{\text { Height }(\mathrm{cm})}{\text { Root Collar Diameter }(\mathrm{mm})}
\end{gathered}
$$




$$
D Q I=\frac{\text { Total dry weight of the plant }}{\frac{H(\mathrm{~cm})}{R C D(\mathrm{~mm})}+\frac{A D B(\mathrm{~g})}{R D B(\mathrm{~g})}}
$$

Where: $H$ is height, in $\mathrm{cm} ; A D B$ is aerial dry biomass; $R D B$ is root dry biomass; $R C D$ is root collar diameter.

The data were analyzed with variance (ANOVA) with the factorial design. Those variables that showed significant differences were subjected to Tukey's multiple means comparison test, with a significance level of $\mathrm{P} \leq 0.05$, using Statistica, 2003.

\section{RESULTS AND DISGUSSION}

The results showed that the fertilizers evaluated in their different doses had a significant influence $(\mathrm{P} \leq 0.05)$ on the variables related to the growth and development of caracolillo plants (height, diameter and number of leaves). The best results were obtained with the application of Basacote ${ }^{\circledR}$. Although Multicote ${ }^{\circledR}$ in its low dose showed statistically equal results to the first one. Regarding application rates, the three variables evaluated were significantly higher $(\mathrm{P} \leq 0.05)$ when applying the lowest $\left(10 \mathrm{~kg} \mathrm{~m}^{-3}\right)$, and decreased as the dose increased. Fertilization in its different doses had a statistically significant effect on the growth in height of the caracolillo plants. Figure 1 shows the behavior of this variable in the last measurement (week 15), where it can be clearly observed that the highest growth in height was obtained with the low doses $\left(10 \mathrm{~kg} \mathrm{~m}^{-3}\right.$ ) of both fertilizers (Basacote ${ }^{\circledR}$ and Multicote ${ }^{\circledR}$ ), and in the case of Basacote ${ }^{\circledR}$ this same result can be observed in its medium dose $\left(20 \mathrm{~kg} \mathrm{~m}^{-3}\right)$, showing significant statistical differences in relation to the control treatment, the remaining treatments and the control were statistically equal. According to Morales-Pérez (2018), the height of tropical forest plants should range between 15 and $30 \mathrm{~cm}$ so that they can be catalogued with good development in the nursery stage, which ensures their survival in the field; in this sense, the evaluated plants presented mean values within the suggested range $(17$ to $20 \mathrm{~cm})$ for their release to the field.

Regarding diameter, in this last measurement, the low doses $\left(10 \mathrm{~kg} \mathrm{~m}^{-3}\right)$ of both fertilizers were the ones with the greatest increase (Figure 2), showing significant statistical differences in relation to the other doses (except Basacote in the medium dose) and the control, which, according to the results, did not show significant statistical differences between them.

Table 1. Values that qualify plant quality with normal growth in a forest nursery.

\begin{tabular}{c|c|c|c}
\hline Quality index & High & Medium & Low \\
\hline RI & $<6.0$ & 6.0 a 8.0 & $>8.0$ \\
\hline BSA/BSR & 1.5 a 2.0 & 2.0 a 2.5 & $>2.5$ \\
\hline DCI & $>0.5$ & 0.2 a 0.5 & $<0.2$ \\
\hline
\end{tabular}

$\mathrm{RI}=$ robustness index; $\mathrm{ADB} / \mathrm{RDB}=$ aerial and root dry biomass; $\mathrm{DCI}=$ Dickson's quality index. 


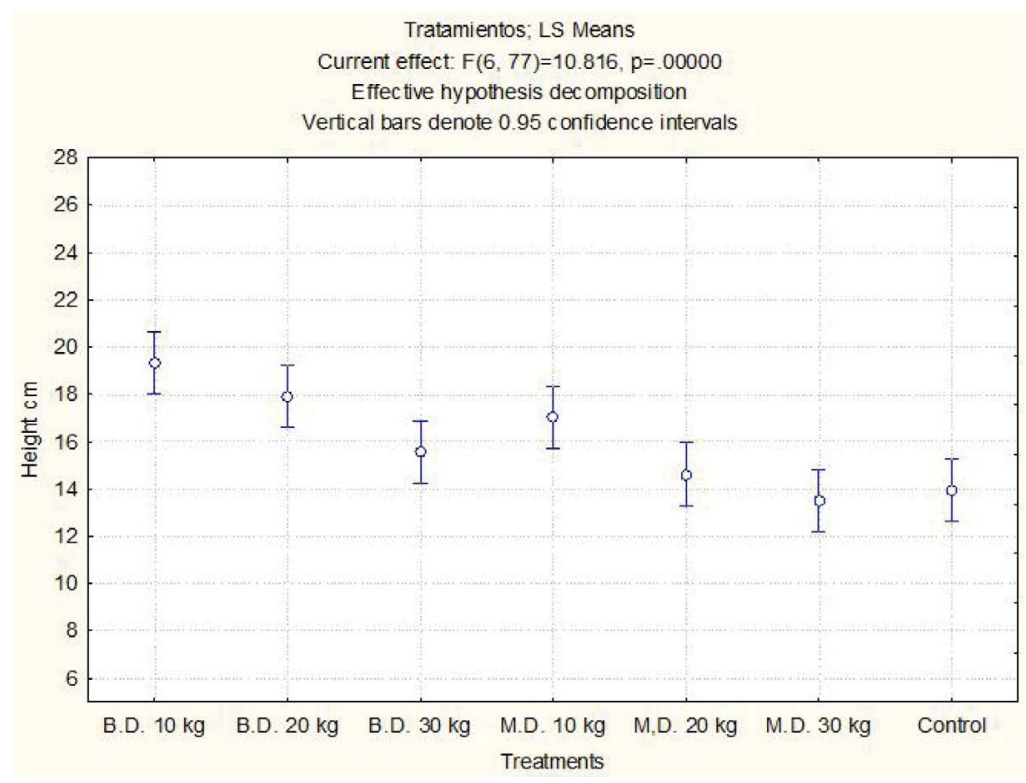

Figure 1. Height $(\mathrm{cm})$ of caracolillo plants (nursery stage) of 15 weeks, with three doses of the controlled release fertilizers Basacote ${ }^{\circledR}$ and Multicote ${ }^{\circledR}$. Vertical bars indicate the confidence interval $(0.95)$.

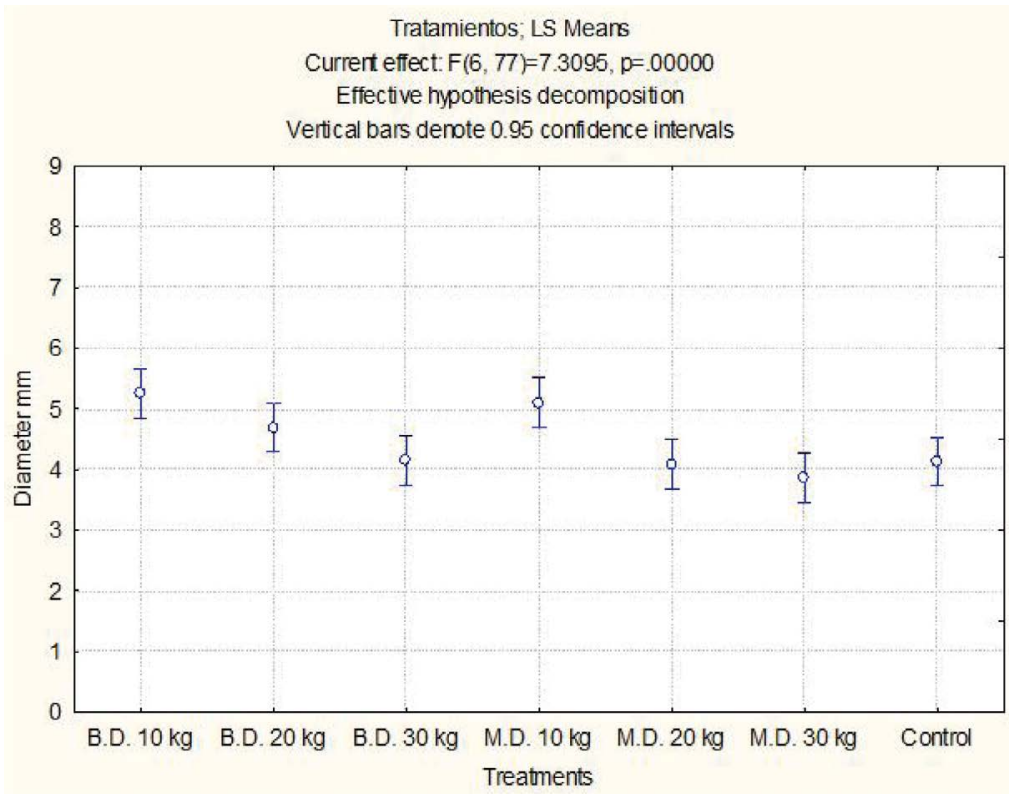

Figure 2. Diameter of caracolillo plants (nursery stage) of 15 weeks, with three doses of controlled release fertilizers, Basacote ${ }^{\circledR}$ and Multicote ${ }^{\circledR}$. Vertical bars indicate the confidence interval (0.95).

Plants with diameters of 5 to $6 \mathrm{~mm}$ are more resistant to bending and tolerate better damage from pests and harmful fauna (CONAFOR, 2009). For the case of caracolillo, the average diameter of the low doses fluctuated between 5 and $6 \mathrm{~mm}$, which can be considered as good, since the average value was above the suggested value (5 mm) (Sáenz et al., 2010). On the contrary, the control treatment and the high doses presented values below this range. The CRFs have the advantage of releasing nutrients at a rate that 
coincides with the plant's demand, thus avoiding losses from decreasing the frequency of fertilization, or from leaching, volatilization, or degradation, favoring plant quality (Reyes-Castro et al., 2020).

Regarding the number of leaves, the low doses of both fertilizers presented the highest number, in relation to the control treatment (Figure 3); the latter was statistically equal to the medium and high doses of Multicote ${ }^{\circledR}$ fertilizer, but different from the low doses of both fertilizers, as well as the medium and high doses of Basacote ${ }^{\circledR}$ fertilizer. The plants had an average of seven and ten leaves in each treatment. The number of leaves is related to various physiological processes such as photosynthetic efficiency and transpiration area, in addition to representing the plant's capacity to store carbohydrates (Prieto et al., 2009).

As for the quality indices, the RI varied between 3.4 and 4.0, an interval that corresponds to high quality plants in all treatments, although there were no statistical differences between them (Figure 4). Basacote ${ }^{\circledR}$ in its low and medium doses showed the highest average values. Prieto et al. (2009) indicate that plants with values lower than six are considered to be of high quality, robust, with vigorous stems, and apt to develop in sites with moisture limitations, in addition to being an indicator of the plant's resistance to desiccation by the wind.

The values of $\mathrm{ADB} / \mathrm{RDB} \mathrm{R}$ denote low quality plants (>2.5) in all cases (Figure 5), with the high dose of Basacote ${ }^{\circledR}$ fertilizer being the treatment that presents the lowest quality interval (highest value of $\mathrm{ADB} / \mathrm{RDB} \mathrm{R}$ ); the value obtained in the control treatment presents the best quality characteristic (lowest value of $\mathrm{ADB} / \mathrm{RDB} \mathrm{R}$ ), although statistically equal to the other treatments, except for Basacote ${ }^{\circledR}$ in its high dose (Reyes Castro et al., 2020).

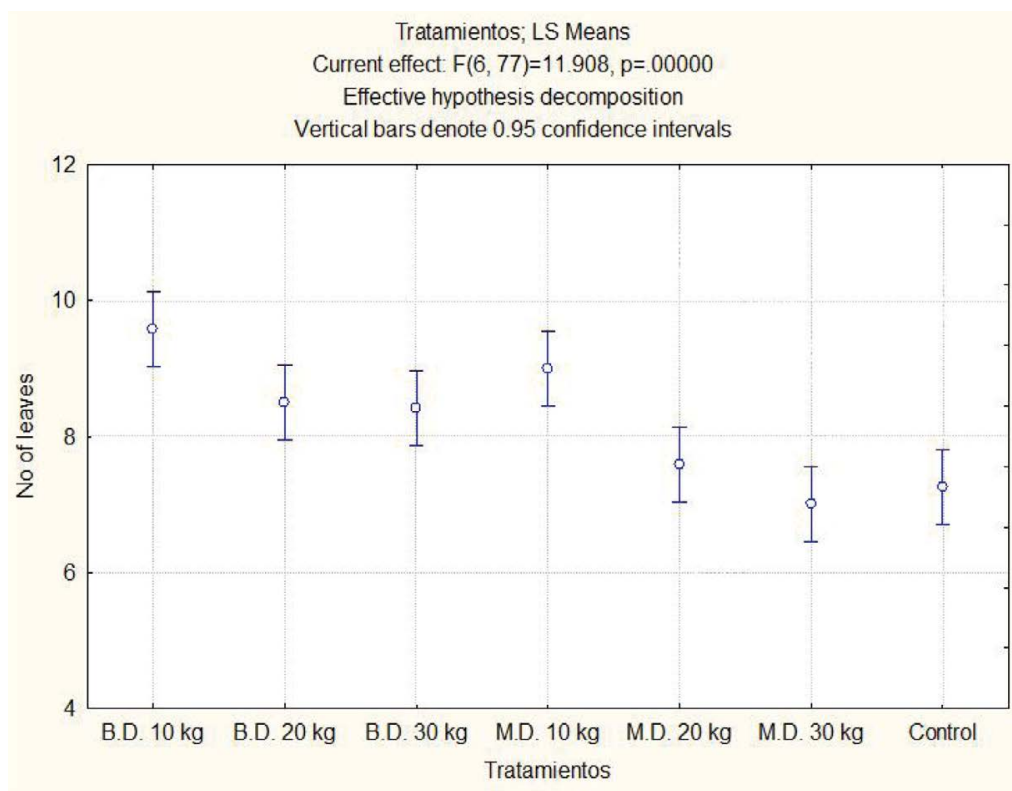

Figure 3. Statistical analysis of number of leaves in caracolillo plants (nursery stage) of 15 weeks, with three doses of controlled release fertilizers, Basacote ${ }^{\circledR}$ and Multicote ${ }^{\circledR}$. The vertical bars indicate the confidence interval (0.95). 


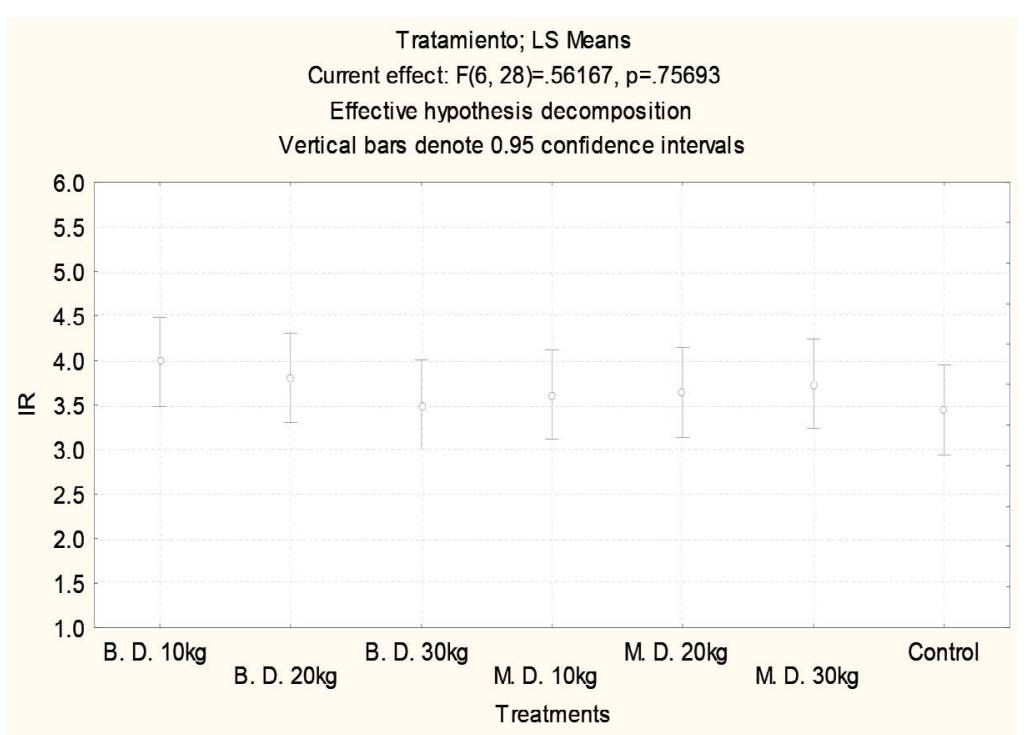

Figure 4. Statistical analysis of the robustness index in the nursery stage caracolillo plants, at week 15 . Vertical bars indicate the confidence interval (0.95).

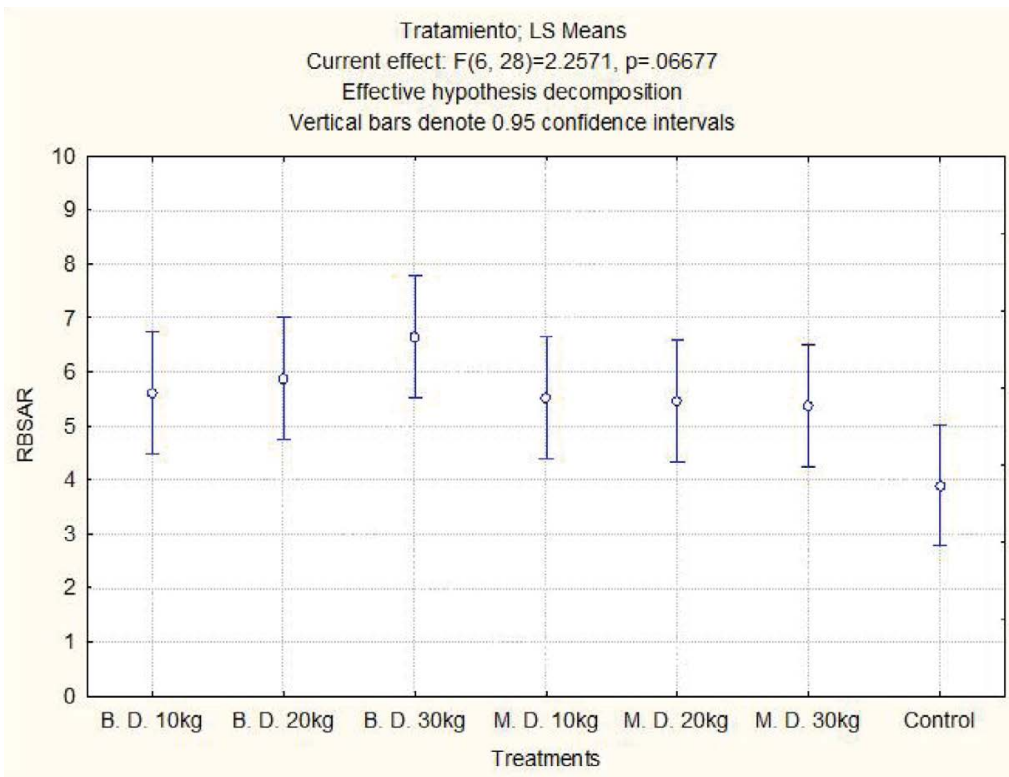

Figure 5. Effect of fertilizer doses on the aerial dry biomass/root dry biomass relationship of caracolillo plants nursery stage, in week 15 . Vertical bars indicate the confidence interval (0.95).

In Dickson's quality index (DQI), the results did not show significant statistical differences between treatments (Figure 6); they all corresponded to high quality plants. However, the best results were obtained with the low and medium doses of Basacote ${ }^{\circledR}$ fertilizer, with the low dose having the best average value, followed by the low dose of Multicote ${ }^{\circledR}$ and the control treatment, which presented values within the intervals suggested by Sáenz et al. (2010), who indicate that high quality plants are those with indexes $>0.5$. 


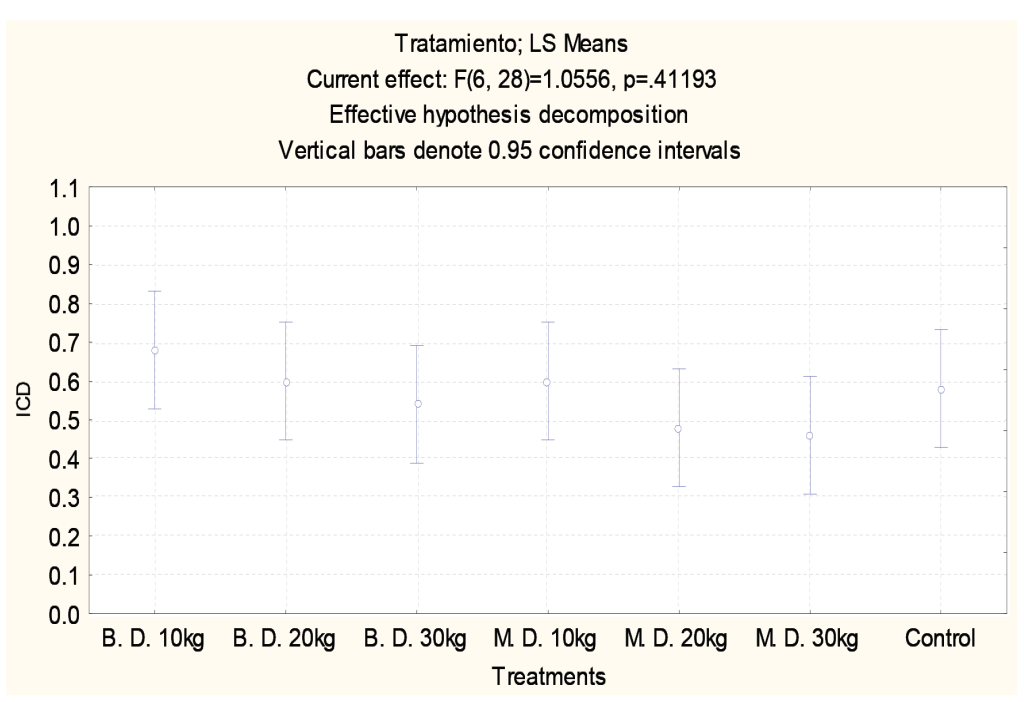

Figure 6. Effect of the fertilizer dose on the ratio of DQI in caracolillo plants (nursery stage) in week 15. The vertical bars indicate the confidence interval $(0.95 \%)$.

\section{CONGLUSIONS}

The controlled release fertilizers Basacote ${ }^{\circledR}$ and Multicote ${ }^{\circledR}$ in their low doses $\left(10 \mathrm{~kg} \mathrm{~m}^{-3}\right)$ were, in general, the treatments that showed the best results in growth and development of caracolillo in the nursery stage. However, with respect to the robustness index (RI), aerial/ radical dry biomass ratio $(\mathrm{ADB} / \mathrm{RDB} \mathrm{R})$ and Dickson quality index (DQI), the treatments did not show significant statistical differences.

\section{REFERENGES}

Carpenedo A.S., M. Machado A., E. Benítez L., G. Gómez O., y F. da Silva C. 2016. Volumen de contenedores y dosis de fertilizante de liberación controlada en el crecimiento de plantas de Cabralea canjerana producidas en vivero. Bosque. 37(2): 401-407.

Castro-Garibay S.L., A. Aldrete, J. López-Upton, y V.M. Ordáz-Chaparro. 2018. Efecto del envase, sustrato y fertilización en el crecimiento de Pinus greggii var. australis en vivero. Agrociencia. 52: 115-127.

CONAFOR (Comisión Nacional Forestal). 2009. Criterios técnicos para la producción de especies forestales de ciclo corto (rápido crecimiento), con fines de restauración. Documento técnico. Guadalajara, Jal. México. 9 pp.

Escamilla-Hernández N., J.J. Obrador-Olán, E. Carrillo-Ávila y D.J. Palma-López. 2015. Uso de fertilizantes de liberación controlada en plantas de teca (Tectona grandis), en la etapa de vivero. Fitotec. Mex. 38(3):329-333.

González-Orozco M.M., J.Á. Prieto R., A. Aldrete, J.G. Hernández D., J.A. Chávez S., R. Rodríguez L. 2018. Raw sawdust substrates and fertilization in the plant quality of Pinus cooperi Blanco seedlings grown at the nursery. Revista Mexicana de Ciencias Forestales. 9(48):1-23.

Landis, T.D., R.W. Tinus, S.E. MacDonald, J.P. Barnett, R.G. Nisley, D.T. Rodríguez, R.V. Sánchez y R.B. Aldana. 2004. Manual de Viveros para la Producción de Especies Forestales en Contenedor. Dpto. de Agricultura de los Estados Unidos. Servicio Forestal. Portland, Oregon, USA. 192 pp.

Maldonado-Benítez K.R., A. Aldrete, J. López-Upton, H. Vaquera-Huerta, y V.M. Cetina-Alcalá. 2011. Nursery production of Pinus greggii Engelm. in mixtures of substrate with hydrogel and irrigation levels. Agrociencia. 45:389-398.

Oliet J., M.L. Segura, F. Martín, E. Blanco, E. Serrada R., M. López A., y F. Artero. 1999. Los fertilizantes de liberación controlada lenta aplicados a la producción de planta forestal de vivero. Efecto de dosis y formulaciones sobre la calidad de Pinus halepensis Mill. Invest. Agr. Sist. Recur. For. 8(1):208-228.

Orozco-Gutiérrez G., H.J. Muñoz-Flores, F. Villaseñor-Ramírez, A. Rueda-Sánchez, J.Á. Sígala-Rodríguez y J. Á. Prieto-Ruíz. 2010. Diagnóstico de la calidad de planta en los viveros forestales del estado de 
Colima. Folleto Técnico Núm. 1. Campo Experimental Uruapan. Centro de Investigación Regional Pacífico Centro. INIFAP. Uruapan, Michoacán, México. 47 pp.

Palma-López D. J., J. Cisneros D., E. Moreno C. y J.A. Rincón-Ramírez. 2007. Suelos de Tabasco: su uso y manejo sustentable. Colegio De Postgraduados-Isprotab. Fundación Produce Tabasco. Villahermosa, Tabasco, México.

Pérez-Hernández I., S. Ochoa-Gaona, G. Vargas-Simón, M. Mendoza-Carranza, y N. A. González-Valdivia. 2011. Germinación y supervivencia de seis especies nativas de un bosque tropical de Tabasco, México. Madera y Bosques. 17(1):71-91.

Prieto J.A., García J.L., Mejía J.M., Huchin A.S., y Aguilar J.L. 2009. Producción de planta del Género Pinus en vivero en clima templado frío. Publicación Especial Núm. 28. Campo Experimental Valle del Guadiana. Centro de Investigación Regional Norte Centro. INIFAP. Durango, Dgo. México. 47 pp.

Prieto J.A., y Sáenz J.T. 2011. Indicadores de la calidad de planta en viveros de la sierra madre occidental. Libro Técnico Núm. 3. Campo Experimental Valle del Guadiana. Centro de Investigación Regional Norte Centro. INIFAP. Durango, Dgo. México. 212 pp.

Reyes-Castro R., J. Arreola-Enríquez, E. Carrillo-Ávila, J.J. Obrador-Olán, 2020. Evaluation of the conventional and controlled release fertilization, on the quality of jagua plants (Genipa americana L.) in nursery. Agroproductividad. 13 (5):43-49.

Sáenz R. J. T., Villaseñor R. F. J., Muñoz F. H. J., Rueda S. A. y Prieto R. J. A. 2010. Calidad de planta en viveros forestales de clima templado en Michoacán. Folleto Técnico No. 17. SAGARPA-INIFAPCIRPAC-Campo Experimental Uruapan. Uruapan, Michoacán, México. 48 pp.

SEMARNAT. 2010. Norma Oficial Mexicana NOM-059-SEMARNAT-2010, Protección ambiental-Especies nativas de México de flora y fauna silvestres: Categorías de riesgo y especificaciones para su inclusión, exclusión o cambio-Lista de especies en riesgo. Ciudad de México. Secretaría del Medio Ambiente y Recursos Naturales. Diario Oficial de la Federación.

SERFOR (Servicio Nacional Forestal). 2016. Metodología para la determinación del valor al estado natural de la madera para el pago de derecho del aprovechamiento" y los "Valores al estado natural de la madera. Resolución de dirección ejecutiva N²41-2016. El Peruano. Normas Legales. 4 pp.

Terán-Soto A.C. 2018. Efecto de dos fertilizantes de liberación controlada sobre el crecimiento de Pinus tecunumanii en la etapa de vivero Oxapampa. Tesis. Lima, Perú. Universidad Nacional Agraria a Molina. Facultad de Ciencias Forestales. 77 pp.

Vargas-Simón G., M.L. Núñez-Piedra, M. Domínguez-Domínguez, W.R. Alegría-González, P. MartínezZurimendi. 2018. Distribución de Ormosia macrocalyx en México y delimitación de sus áreas de ocupación. Revista Mexicana de Biodiversidad. 89: 1201- 211.

Villalón-Mendoza H., J.C. Ramos-Reyes, J.A. Vega-López, B. Marino, M.A. Muños-Palomino, y F. GarzaOcañas. 2016. Indicadores de calidad de la planta de Quercus canby Trel. (encino) en vivero forestal. Latinoamericana de Recursos Naturales 12(1): 46-52. 